\title{
Erratum to: Ectopic ACTH secretion associated to a well-differentiated peritoneal mesothelioma
}

\author{
Carmen F. Mendoza ${ }^{1 \dagger}$, Patricia Ontiveros ${ }^{2}$, Daniel X. Xibillé ${ }^{3+}$ and Heriberto Manuel Rivera ${ }^{4^{*}}$
}

\section{Erratum to: BMC Endocrine Disorders \\ doi: 10.1186/s12902-015-0031-4}

Unfortunately the publication the original version of this article in BMC Endocrine Disorders [1] contained an error. The funding of the paper was not mentioned in the original version. However, the published paper was funded by the Fondo Mixto-Consejo Nacional de Ciencia y Tecnología and Morelos Government [Grant MOR-2013C01-224236] and the Programa de Mejoramiento del Profesorado [Grant 103.5/13/8913 PTC-300] (to H.M.R.). Additionally, the name of author Heriberto Manuel Rivera was incorrectly spelled as Manuel H. Rivera, Author Heriberto Manuel Rivera is the corresponding author of the paper instead of author Carmen F. Mendoza.

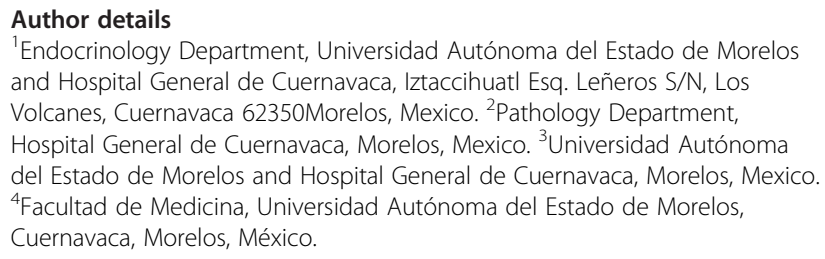

Received: 9 September 2015 Accepted: 9 September 2015

Published online: 14 September 2015

\section{Reference}

1. Mendoza CF, Ontiveros P, Xibillé DX, Rivera HM. Ectopic ACTH secretion associated to a well-differentiated peritoneal mesothelioma. BMC Endocrine Disorders. 2015;15:40.

\footnotetext{
* Correspondence: m2mrivera@uaem.mx

${ }^{\dagger}$ Equal contributors

${ }^{4}$ Facultad de Medicina, Universidad Autónoma del Estado de Morelos, Cuernavaca, Morelos, México

Full list of author information is available at the end of the article
}

\author{
Submit your next manuscript to BioMed Central \\ and take full advantage of: \\ - Convenient online submission \\ - Thorough peer review \\ - No space constraints or color figure charges \\ - Immediate publication on acceptance \\ - Inclusion in PubMed, CAS, Scopus and Google Scholar \\ - Research which is freely available for redistribution
}

Submit your manuscript at

www.biomedcentral.com/submit

( Biomed Central

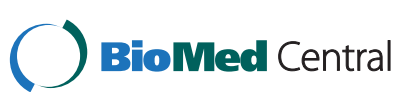

(c) 2015 Mendoza et al. Open Access This article is distributed under the terms of the Creative Commons Attribution 4.0 International License (http://creativecommons.org/licenses/by/4.0/), which permits unrestricted use, distribution, and reproduction in any medium, provided you give appropriate credit to the original author(s) and the source, provide a link to the Creative Commons license, and indicate if changes were made. The Creative Commons Public Domain Dedication waiver (http://creativecommons.org/publicdomain/zero/1.0/) applies to the data made available in this article, unless otherwise stated. 